\title{
REVIEW
}

\section{Updating the evidence. A systematic review of what works in preventing childhood unintentional injuries: Part 2}

\author{
E Towner, T Dowswell, S Jarvis
}

Part 1 of this paper was published in June (Inj Prev 2001;7:161-4)

Department of Child Health, University of Newcastle, UK

E Towner

T Dowswell

S Jarvis

Correspondence to: Dr E Towner, Community Child Health, 13 Walker

Terrace, Gateshead

NE8 1EB, UK

E.L.M.Towner@ncl.ac.uk

\section{Injuries in the home environment}

Four recent studies focus on the prevention of home accidents at a general level. ${ }^{1-4}$ These papers suggest that, while educational campaigns and equipment loan schemes may be potentially effective in terms of promoting behavioural change, there is little evidence that injury reductions are achieved by these means (table 1).

There is increasing evidence from the United States of the positive effect of campaigns promoting the use of smoke alarms (table 2). ${ }^{5-9}$ A smoke alarm giveaway programme in the central area of Oklahoma City, where there was a high fire risk, showed an $80 \%$ annual injury rate decline from $15.3 / 100000$ to $3.1 / 100000$, compared with a slight increase in the rest of the city. ${ }^{5}$ The authors point out that, "interventions that target areas with high rates of fires may be especially efficient ways to lower the incidence of injuries and deaths from residential fires". This is the first community based study to demonstrate the effectiveness of a smoke alarm promotion programme on health outcomes. There is also evidence that smoke alarm promotion programmes lead to changes in behaviour which are sustained over a long period of time (3-4 years), resulting in greater numbers of households with functioning smoke alarms. ${ }^{7}$

Additional evidence related to the prevention of childhood poisoning comes from a long term follow up of legislation in the United States introduced in 1974, which required child resistant packaging for all prescription drugs. ${ }^{10}$ For children aged $0-4$ years the mortality rate for oral prescription drugs declined from 3.5 per million in the late 1960s (before legislation), to fewer than 2 deaths per million in the early 1990s. This represented 460 fewer deaths for the period 1974 to 1992 (table 3)..$^{11}$

\section{Injuries in the leisure environment}

There remains very little evidence regarding the effectiveness of health promotion in preventing injuries in the leisure environment (table 4). ${ }^{12-16}$

An Australian study of an educational intervention, directed at parents and teachers, aimed to increase compliance with safety standards in school playgrounds. There was a small improvement in the number of hazards observed in school playgrounds after the intervention. ${ }^{14}$ A study conducted in Wales evaluated the effect of environmental changes to playgrounds, including increasing the depth of bark surfaces in some playgrounds and changes in playground equipment. Changes in injury rates and in rates of fractures were noted. ${ }^{16}$

Two papers describing interventions, set within the leisure environment, by D'Argenio

Table 1 The home environment: prevention of general home accidents

\begin{tabular}{|c|c|c|c|c|c|}
\hline $\begin{array}{l}\text { Author, date, and } \\
\text { country }\end{array}$ & $\begin{array}{l}\text { Injury target group } \\
\text { and setting }\end{array}$ & Aims and content of intervention & $\begin{array}{l}\text { Study type and } \\
\text { sample size }\end{array}$ & Outcome measures & Key results \\
\hline $\begin{array}{l}\text { Bablouzian et al } \\
\quad(1997),{ }^{1} \text { USA }\end{array}$ & $\begin{array}{l}\text { Preschool. Low } \\
\text { income. Home } \\
\text { setting }\end{array}$ & $\begin{array}{l}\text { Healthy Baby Program } \\
\text { Home visits, counselling, and } \\
\text { safety assessment }\end{array}$ & $\begin{array}{l}\text { Before and after } \\
\text { study } I=72\end{array}$ & $\begin{array}{l}\text { (A) Observed hazards } \\
\text { (B) Knowledge }\end{array}$ & $\begin{array}{l}\text { (A) Reduction for } 4 \text { hazards. (B) Reported } \\
\text { increased use of safety restraints in cars } \\
\text { Partially effective Reasonable/weak } \\
\text { evidence }\end{array}$ \\
\hline $\begin{array}{l}\text { Clamp and } \\
\text { Kendrick } \\
(1998),{ }^{2} \text { UK }\end{array}$ & $\begin{array}{l}0-5 \text { years. Low } \\
\text { income. Primary } \\
\text { care settings }\end{array}$ & $\begin{array}{l}\text { General practitioner safety } \\
\text { advice. Single } 20 \text { minutes } \\
\text { consultation. Subsidised } \\
\text { smoke alarms and other safety } \\
\text { equipment }\end{array}$ & $\begin{array}{l}\text { Randomised } \\
\text { controlled trial } \\
\mathrm{I}=83 \text { families } \\
\mathrm{C}=82 \text { families }\end{array}$ & $\begin{array}{l}\text { (A) Reported behaviour } \\
\text { Use of safety equipment }\end{array}$ & $\begin{array}{l}\text { (A) Use of safety equipment increased in I } \\
\text { families (for example, fireguards } 36 / 65 v \\
19 / 60 \text { controls) Effective in short term } \\
\text { Good/reasonable evidence }\end{array}$ \\
\hline $\begin{array}{l}\text { Thompson et al } \\
\text { (1998), }{ }^{3} \mathrm{UK}\end{array}$ & $\begin{array}{l}\text { Under } 5 \text { years. } \\
\text { Low income areas. } \\
\text { Home }\end{array}$ & $\begin{array}{l}\text { Home safety equipment loan } \\
\text { schemes and health visitor } \\
\text { counselling }\end{array}$ & $\begin{array}{l}\text { Before and after } \\
\text { study }\end{array}$ & $\mathrm{A}$ and $\mathrm{E}$ attendance data & $\begin{array}{l}\text { Home accidents in children under } 510 \% \\
\text { decrease } 1990-94 . \text { Not able to demonstrate } \\
\text { effect on injury outcomes Inconclusive } \\
\text { Reasonable/weak evidence }\end{array}$ \\
\hline $\begin{array}{l}\text { Kendrick et al } \\
\quad(1999),{ }^{4} \text { UK }\end{array}$ & $\begin{array}{l}0-2 \text { years. Primary } \\
\text { care. Component } \\
\text { targeting deprived } \\
\text { community }\end{array}$ & $\begin{array}{l}\text { I=targeted advice, low cost } \\
\text { safety equipment, home safety } \\
\text { checks and first aid training } \\
\mathrm{C}=\text { routine child surveillance }\end{array}$ & $\begin{array}{l}\text { Randomised } \\
\text { controlled trial } \\
\mathrm{I}=18 \mathrm{GP} \text { practices } \\
\mathrm{n}=1124 \text { children } \\
\mathrm{C}=18 \mathrm{GP} \text { practices } \\
\mathrm{n}=1028 \text { children }\end{array}$ & $\begin{array}{l}\text { (A) Medically attended } \\
\text { injuries. (B) Self reported } \\
\text { behaviour. (C) } \\
\text { Knowledge. (D) } \\
\text { Penetration of } \\
\text { intervention }\end{array}$ & $\begin{array}{l}\text { (A) No significant differences between I and } \\
\text { C groups. (B) No differences in unsafe } \\
\text { practices between I and C. (C) No } \\
\text { differences in knowledge in I and C. (D) In } \\
\text { I } 22 \% \text { no interventions, } 27 \% 1 \text { intervention } \\
\text { Ineffective Good/reasonable evidence }\end{array}$ \\
\hline
\end{tabular}


Table 2 The home environment: prevention of burns and scalds

\begin{tabular}{|c|c|c|c|c|c|}
\hline $\begin{array}{l}\text { Author, date, and } \\
\text { country }\end{array}$ & $\begin{array}{l}\text { Injury target group } \\
\text { and setting }\end{array}$ & $\begin{array}{l}\text { Aims and content of } \\
\text { intervention }\end{array}$ & $\begin{array}{l}\text { Study type and sample } \\
\text { size }\end{array}$ & Outcome measures & Key results \\
\hline $\begin{array}{l}\text { Mallonee et al } \\
\quad(1996),{ }^{5} \text { USA }\end{array}$ & $\begin{array}{l}\text { Total population. } \\
\text { Low income. High } \\
\text { risk groups. Home } \\
\text { setting }\end{array}$ & $\begin{array}{l}\text { Smoke alarm giveaway } \\
\text { programme. Door to door } \\
\text { distribution and supporting } \\
\text { educational material }\end{array}$ & $\begin{array}{l}\text { Controlled trial } \\
\text { without } \\
\text { randomisation } \mathrm{I}=73 \\
301 \text { in } 24 \text { square mile } \\
\text { area } \mathrm{C}=\text { rest of } \\
\text { Oklahoma }\end{array}$ & $\begin{array}{l}\text { (A) Mortality and } \\
\text { morbidity data. (B) } \\
\text { Observed behaviour }\end{array}$ & $\begin{array}{l}\text { (A) In } 4 \text { years annual injury rate declined } \\
80 \% \text {, from } 15.3 \text { to } 3.1 / 100000 \text { compared to } \\
\text { an increase of } 8 \% 3.6 \text { in I to } 3.9 / 100000 \text { in } \\
\text { C Injury rate per } 100 \text { residential fires } \\
\text { decreased } 74 \% \text { in I and increased } 32 \% \text { in C } \\
\text { (B) } 45 \% \text { of alarms still functioning } 4 \text { years } \\
\text { later Effective Good/reasonable evidence }\end{array}$ \\
\hline $\begin{array}{r}\text { McConnell et al } \\
\quad(1996),{ }^{6} \text { USA }\end{array}$ & $\begin{array}{l}3-5 \text { years attending } \\
\text { child care centres }\end{array}$ & $\begin{array}{l}\text { "Kid Safe" program To } \\
\text { increase fire safety knowledge } \\
\text { by a classroom programme. } \\
30 \text { hours over } 18 \text { weeks } \\
\text { including role play and } \\
\text { simulation }\end{array}$ & $\begin{array}{l}\text { Controlled trial with } \\
\text { random allocation at } \\
\text { group level } I=6 \text { child } \\
\text { care centres } C=4 \\
\text { child care centres }\end{array}$ & $\begin{array}{l}\text { Pre-test and post-test } \\
\text { Knowledge scores of } \\
\text { children aged } 3,4 \text { and } \\
5 \text { years }\end{array}$ & $\begin{array}{l}3 \text { year old children: knowledge scores } \\
\text { increased by } 30.2 \text { in I, and } 10 \text { in C } 4 \text { year } \\
\text { old children: scores increased by } 22 \text { in I and } \\
12 \text { in C } 5 \text { year old children: scores increased } \\
20.9 \text { in I and } 7.3 \text { in C Effective } \\
\text { Good/reasonable evidence }\end{array}$ \\
\hline $\begin{array}{l}\text { Shults et al } \\
\quad(1998),{ }^{7} \text { USA }\end{array}$ & $\begin{array}{l}\text { General population. } \\
\text { Older adults and } \\
\text { children under } 5 \text {. } \\
\text { Home setting }\end{array}$ & $\begin{array}{l}3 \text { smoke detector promotion } \\
\text { programmes: } I_{1} \text { Home } \\
\text { inspections and installation of } \\
\text { detectors, } \mathrm{I}_{2} \text { Detectors } \\
\text { distributed and installed to } \\
\text { households requesting them, } \\
\mathrm{I}_{3} \text { Oklahoma-door to door } \\
\text { distribution ( }<10 \% \text { installed) }\end{array}$ & $\begin{array}{l}\text { Before and after } \\
\text { studies to } 3 \text { different } \\
\text { groups: } \mathrm{I}_{1}=338 \\
\text { Minnesota, } \mathrm{I}_{2}=702 \\
\text { North Carolina, } \\
\mathrm{I}_{3}=9291 \text { Oklahoma }\end{array}$ & $\begin{array}{l}\text { Observed behaviour } \\
\text { Reported behaviour }\end{array}$ & $\begin{array}{l}\text { Overall } 88 \% \text { of households had at least one } \\
\text { smoke detector on premises and } 64 \% \text { at } \\
\text { least one functioning device. Battery } \\
\text { replaced as part of follow up: } 79 \% \mathrm{I}_{1}, 93 \% \\
\mathrm{I}_{2}, 73 \% \mathrm{I}_{3} \text { had functioning detectors at end } \\
\text { of follow up Partially effective Reasonable } \\
\text { evidence }\end{array}$ \\
\hline $\begin{array}{l}\text { DiGuiseppi et al } \\
\quad(1999),{ }^{8} \mathrm{UK}\end{array}$ & $\begin{array}{l}\text { General population. } \\
\text { Deprived } \\
\text { communities. Home } \\
\text { setting }\end{array}$ & $\begin{array}{l}\text { Smoke detector giveaway } \\
\text { campaign and fire safety } \\
\text { information }\end{array}$ & $\begin{array}{l}\text { Randomised } \\
\text { controlled trial } \mathrm{I}=20 \\
\text { inner city wards } \\
\text { (approx } 80000 \\
\text { households) } \mathrm{C}=20 \\
\text { inner city wards }\end{array}$ & $\begin{array}{l}\text { (A) Alarm distribution } \\
\text { (B) Process and } \\
\text { impact measures }\end{array}$ & $\begin{array}{l}\text { (A) } 20050 \text { alarms distributed. (B) } \\
\text { Programme cost: } £ 145087 \text { Effective } \\
\text { Good/reasonable evidence (Preliminary } \\
\text { results only reported) }\end{array}$ \\
\hline $\begin{array}{l}\text { King et al } \\
\quad(1999),{ }^{9} \\
\text { Australia }\end{array}$ & $\begin{array}{l}0-4 \text { years. } \\
\text { Vietnamese, } \\
\text { Chinese, and Arabic } \\
\text { families. Mass media }\end{array}$ & $\begin{array}{l}\text { Mass media campaign. } \\
\text { Information distributed via } \\
\text { newspapers and radio. In } \\
\text { appropriate languages }\end{array}$ & $\begin{array}{l}\text { Before and after } \\
\text { study without control } \\
\text { group. Before: } 254 \\
\text { After: } 302\end{array}$ & $\begin{array}{l}\text { (A) Knowledge } \\
\text { (B) Impact }\end{array}$ & $\begin{array}{l}\text { (A) Knowledge of correct first aid increased } \\
\text { from } 42 \% \text { before to } 63 \% \text {. (B) } 40 \% \text { aware of } \\
\text { the campaign Partially effective Reasonable } \\
\text { evidence }\end{array}$ \\
\hline
\end{tabular}

$\mathrm{C}=$ control; $\mathrm{I}=$ intervention .

et $a l^{12}$ and Malinowska-Cieslik and Borne ${ }^{13}$ provide examples of innovative content. These two interventions highlight the importance of the cultural setting of some interventions.

\section{Community-wide studies}

Five recent papers evaluate community based interventions (table 5). ${ }^{17-21}$ The findings of these studies are not simple to interpret. While there is some evidence that such programmes can result in health gain, the quality of the evidence is limited.

\section{Mass media interventions}

Table 6 summarises findings relating to mass media and more general training events. ${ }^{22-24}$ Exhibitions and public information campaigns can increase knowledge, but there is no new evidence that such approaches have any impact on injury rates.

\section{New target groups and implementation strategies}

In our first systematic review of childhood injury prevention studies, published in 1993, very few intervention studies targeted deprived groups in society, despite the strong associations between social deprivation and childhood injury. ${ }^{25}$ Our second review, published in 1996, contained more studies which targeted social deprivation. ${ }^{26}$ This trend has continued in the current review. Between 1995 and 1998 studies which have targeted deprived groups or communities include Thomson and Whelan's evaluation of practical roadside training of children in a deprived area of Glasgow. ${ }^{27}$ Bicycle helmet educational campaigns targeting more deprived groups include programmes evaluated in $\mathrm{Canada}^{28}$ and the United States. ${ }^{29}{ }^{30}$ Economic barriers to helmet purchase were recognised in several programmes where helmets were either distributed free or discount vouchers provided. Mallonee et al's evaluation of a smoke alarm giveaway programme in a high risk, central city location ${ }^{5}$ and four other studies in the home safety field targeted low income families: Bablouzian et al in

Table 3 The home environment: prevention of poisoning

\begin{tabular}{|c|c|c|c|c|c|}
\hline $\begin{array}{l}\text { Author, date, and } \\
\text { country }\end{array}$ & $\begin{array}{l}\text { Injury target group } \\
\text { and setting }\end{array}$ & $\begin{array}{l}\text { Aims and content of } \\
\text { intervention }\end{array}$ & $\begin{array}{l}\text { Study type and } \\
\text { sample size }\end{array}$ & Outcome measures & Key results \\
\hline $\begin{array}{l}\text { Rodgers (1996), }{ }^{10} \\
\text { USA }\end{array}$ & $\begin{array}{l}0-4 \text { years. } \\
\text { Legislation }\end{array}$ & $\begin{array}{l}\text { Child resistant packaging for } \\
\text { prescription drugs } 1974\end{array}$ & $\begin{array}{l}\text { Time series } \\
1964-92\end{array}$ & $\begin{array}{l}\text { Mortality data. National } \\
\text { Centre for Health } \\
\text { Statistics }\end{array}$ & $\begin{array}{l}\text { Mortality rate for prescription drugs } \\
\text { declined from } 3.5 \text { per million in the late } \\
1960 \text { s to <2 deaths per million in early } \\
1990 \text { s. } 460 \text { fewer deaths between } 1974-92 \\
\text { Effective Good/reasonable evidence }\end{array}$ \\
\hline $\begin{array}{l}\text { Liller et al (1998), } \\
\quad \text { USA }\end{array}$ & $\begin{array}{l}5-9 \text { years. School } \\
\text { based }\end{array}$ & $\begin{array}{l}\text { "More Health" poison } \\
\text { prevention lesson and letters } \\
\text { to parents }\end{array}$ & $\begin{array}{l}\text { After study with } \\
\text { control group } \\
I=194 \text { children } \\
\mathrm{C}=184 \text { children }\end{array}$ & $\begin{array}{l}\text { Knowledge. Parent } \\
\text { reported behaviour }\end{array}$ & $\begin{array}{l}\text { I had more knowledge of poisons compared } \\
\text { with C, for example } 99 \% \text { of I recognised } \\
\text { poison centre sticker compared with } 31 \% \text { of } \\
\text { C Inconclusive. Reasonable/weak evidence }\end{array}$ \\
\hline
\end{tabular}

$\mathrm{C}=$ control; $\mathrm{I}=$ intervention . 
Table 4 The leisure environment: prevention of leisure injuries

\begin{tabular}{|c|c|c|c|c|c|}
\hline $\begin{array}{l}\text { Author, date, and } \\
\text { country }\end{array}$ & $\begin{array}{l}\text { Injury target group } \\
\text { and setting }\end{array}$ & $\begin{array}{l}\text { Aims and content of } \\
\text { intervention }\end{array}$ & $\begin{array}{l}\text { Study type and } \\
\text { sample size }\end{array}$ & Outcome measures & Key results \\
\hline $\begin{array}{l}\text { D'Argenio et al } \\
\text { (1996), }{ }^{12} \text { Italy }\end{array}$ & $\begin{array}{l}\text { General } \\
\text { population and } \\
\text { focus on children } \\
10-14\end{array}$ & $\begin{array}{l}\text { "Capodanno Senza } \\
\text { Danno" (New Year's } \\
\text { without Harm!) Firework } \\
\text { campaign and law } \\
\text { enforcement }\end{array}$ & $\begin{array}{l}\text { Before and after } \\
\text { study. I = } 18 \\
\text { emergency rooms }\end{array}$ & $\begin{array}{l}\text { (A) Morbidity } \\
\text { data-emergency room } \\
\text { records. (B) Fireworks } \\
\text { confiscated }\end{array}$ & $\begin{array}{l}\text { (A) In } 10-12 \text { year olds rate of firework injuries } \\
\text { dropped } 51 \% \text { from } 46 / 100000 \text { to } 22.3 / 100 \\
000 \text {. (B) } 12.5 \text { million fireworks confiscated by } \\
\text { police ( } 82 \% \text { more than previous year) } \\
\text { Inconclusive Reasonable/weak evidence }\end{array}$ \\
\hline $\begin{array}{l}\text { Malinowska-Cieslik } \\
\text { and Borne } \\
(1998),{ }^{13} \text { Poland }\end{array}$ & $\begin{array}{l}6-11 \text { years. } \\
\text { Schools and } \\
\text { community }\end{array}$ & $\begin{array}{l}\text { Multimethod mushroom } \\
\text { poisoning prevention } \\
\text { programme }\end{array}$ & $\begin{array}{l}\text { Before and after } \\
\text { study. } I=693 \\
\text { children }\end{array}$ & $\begin{array}{l}\text { (A) Mortality, } \\
\text { morbidity } \\
\text { (B) Knowledge }\end{array}$ & $\begin{array}{l}\text { (A) Unspecified reductions in hospitalisations } \\
\text { and mortality. (B) Knowledge levels increased } \\
\text { Partially effective Reasonable/weak evidence }\end{array}$ \\
\hline $\begin{array}{l}\text { Withaneachi and } \\
\text { Meehan }(1998),{ }^{14} \\
\text { Australia }\end{array}$ & $\begin{array}{l}\text { Primary school } \\
\text { aged children. } \\
\text { School }\end{array}$ & $\begin{array}{l}\text { Educational intervention on } \\
\text { playground safety standards } \\
\text { in school playgrounds }\end{array}$ & $\begin{array}{l}\text { Before and after } \\
\text { study. No control. I } \\
\text { pre-test }=20 \text { schools } \\
\text { Post-test }=19 \text { schools }\end{array}$ & $\begin{array}{l}\text { (A) Observed hazards } \\
\text { in playground }\end{array}$ & $\begin{array}{l}\text { (A) Improvements on most of safety standards } \\
\text { Before } 99 / 125 \text { pieces of equipment met safety } \\
\text { standard on fall height compared with } 88 / 94 \\
\text { Partially effective/inconclusive } \\
\text { Reasonable/weak evidence }\end{array}$ \\
\hline $\begin{array}{l}\text { Bennett et al } \\
\quad(1999),{ }^{15} \text { USA }\end{array}$ & $\begin{array}{l}1-14 \text { years. } \\
\text { Community } \\
\text { based }\end{array}$ & $\begin{array}{l}\text { Drowning prevention } \\
\text { campaign, life vest loan } \\
\text { programme, and bulk } \\
\text { discount schemes }\end{array}$ & $\begin{array}{l}\text { Before and after } \\
\text { study without } \\
\text { control group } \\
\mathrm{I}_{1}=\text { (before) } 332 \\
\mathrm{I}_{3}=\text { (after) } 480\end{array}$ & $\begin{array}{l}\text { Reported ownership } \\
\text { and use of life vests }\end{array}$ & $\begin{array}{l}\text { Reported ownership } 69 \% \text { before and } 75 \% \\
\text { after campaign. Reported use increased from } \\
20 \% \text { to } 29 \% \text { Effective Reasonable/weak } \\
\text { evidence }\end{array}$ \\
\hline $\begin{array}{l}\text { Sibert et al (1999), } \\
\quad \text { Wales, UK }\end{array}$ & $\begin{array}{l}\text { Children using } \\
\text { public } \\
\text { playgrounds }\end{array}$ & $\begin{array}{l}\text { Environmental changes to } \\
\text { playgrounds, depth of } \\
\text { impact absorbing surfaces } \\
\text { (bark) and changes to } \\
\text { equipment }\end{array}$ & $\begin{array}{l}\text { Controlled trial } \\
\text { without } \\
\text { randomisation. } I=5 \\
\text { parks, } C=18 \text { parks } \\
\text { (no changes) }\end{array}$ & $\begin{array}{l}\text { (A) Injury rates } \\
\text { (B) Number of } \\
\text { fractures }\end{array}$ & $\begin{array}{l}\text { In I, (A) Injury rate changed from } 0.719 \\
\text { before to } 0.297 \text { after. In C, from } 0.433 \text { to } \\
0.346 \text { after (B) in I, fractures changed from } 23 \\
\text { to } 6 \text {. In C, from } 12 \text { to } 10 \text { Partially effective } \\
\text { Reasonable evidence }\end{array}$ \\
\hline
\end{tabular}

$\mathrm{C}=$ control; $\mathrm{I}=$ intervention.

the USA who evaluated a community based home hazard reduction programme, ${ }^{1}$ Clamp and Kendrick's study of general practitioner safety advice and provision of safety equipment, ${ }^{2}$ Kendrick et al's package of home safety interventions, ${ }^{4}$ and Thompson et al's study of home safety equipment loan schemes. ${ }^{3}$

We found more evidence of educational interventions which targeted very young children. For example Britt et al targeted children aged 3-4 years in a classroom intervention to increase bicycle helmet use. ${ }^{29}$ McConnell et al evaluated the effect of a fire safety programme in the classroom on the safety knowledge of 3-5 year old children. ${ }^{6}$ Interestingly what emerged in this programme was that knowledge changes were greatest in the youngest age group. What has not been demonstrated, however, is whether such knowledge change leads to changes in behaviour and, at a more general level, doubts remain about the benefits of education in such young children.

Other programmes have employed innovative approaches to deliver programmes. These include Thomson and Whelan's pedestrian training programme in Glasgow where parent volunteers have been recruited to train children (other than their own) in developing safer pedestrian skills. ${ }^{27}$ In some interventions the focus has not been children or parents. Targeting interventions at teachers and childcare staff (along with parents) achieved modest reductions in playground hazards in an Australian study. ${ }^{14}$ Professionals were also targeted in a UK study in an intervention aiming to increase knowledge among health care staff. ${ }^{24}$

\section{Additions to the way interventions have been evaluated}

The study by Ni et al illustrates how a greater use of data collection techniques has been employed in evaluating interventions. ${ }^{31}$ This utilised statewide observation of bicycle helmet use, local observations of use, and self report of helmet use by both children and their parents. This range of sources of data allowed greater confidence in the results. Another study of bicycle helmet promotion, this time targeted at preschool children, used home visits to observe young children playing on bicycles and wearing their helmets. ${ }^{29}$ Observations of helmet wearing are difficult to conduct in this age group and this study represents an innovative approach to attempt to capture this information. A study in the UK evaluating the effects of changes to playgrounds on childhood injuries, included the use of exposure data. ${ }^{16}$ This allowed the rates of injury to be calculated based on a unit of exposure. More specific data on injury type (fractures) were also included in this study. A community based programme from Motala, Sweden, provides the first example in the literature of a study using injury severity data as an outcome. ${ }^{20}$ In the UK, Kendrick et al's trial of a package of interventions delivered in a primary care setting, used both frequency and severity of medically attended injuries as an outcome measure. ${ }^{4}$

Hazinski et al's study of a Children's Traffic Safety Programme made an attempt to assess the level of programme implementation (that is, the degree to which teachers delivered the programme as it had been planned) and compared this with the outcomes achieved. ${ }^{32}$ Schools with good programme implementation achieved better results.

\section{Discussion and conclusions}

The review drew on the world literature on child injury prevention. The search strategy attempted to include a range of databases, including the Transport Research Laboratory road safety database and also included the reference lists of a range of recently published articles. However, some areas, such as product safety and engineering, may be underrepresented, leading to some bias in the results we have reported. 
Table 5 Community based studies

\begin{tabular}{|c|c|c|c|c|c|}
\hline $\begin{array}{l}\text { Author, date, } \\
\text { and country }\end{array}$ & $\begin{array}{l}\text { Injury target group } \\
\text { and setting }\end{array}$ & $\begin{array}{l}\text { Aims and content of } \\
\text { intervention }\end{array}$ & Study type and sample size & Outcome measures & Key results \\
\hline $\begin{array}{l}\text { Svanstrom } e t \\
\text { al (1995), }{ }^{17} \\
\text { Sweden }\end{array}$ & $\begin{array}{l}0-14 \text { years. } \\
\text { Community-wide }\end{array}$ & $\begin{array}{l}\text { Lidköping Accident } \\
\text { Prevention Programme } \\
\text { Bicycle helmet campaigns, } \\
\text { first aid training, loan } \\
\text { schemes, local hazard } \\
\text { removal }\end{array}$ & $\begin{array}{l}\text { Controlled trial without } \\
\text { randomisation. } \mathrm{I}_{1}=\text { Lidköping } \\
35949 . \mathrm{C}_{1}=4 \text { surrounding } \\
\text { municipalities } 42078, \\
\mathrm{C}_{2}=\text { Skarabourg county } \\
278162\end{array}$ & $\begin{array}{l}\text { (A) Hospital } \\
\text { discharge register } \\
\text { data }\end{array}$ & $\begin{array}{l}\text { (A) From } 1983 \text { to } 1991 \text { a reported annual } \\
\text { decrease in hospitalised injuries of } 2.4 \% \\
\text { (boys) and } 2.1 \% \text { (girls) in } \mathrm{I}_{1} . \mathrm{In}_{1} \text {, } \\
\text { increase of } 0.6 \% \text { (boys) and } 2.2 \% \text { (girls). } \\
\text { In } \mathrm{C}_{2} \text { decrease of } 1.0 \% \text { (boys) and } 0.3 \% \\
\text { (girls) Inconclusive Reasonable/weak } \\
\text { evidence }\end{array}$ \\
\hline $\begin{array}{l}\text { Day et al } \\
\quad(1997),{ }^{18} \\
\quad \text { Australia }\end{array}$ & $\begin{array}{l}\text { General } \\
\text { population. } \\
\text { Community-wide }\end{array}$ & $\begin{array}{l}\text { Latrobe Valley Better } \\
\text { Health Project All age } \\
\text { programme to prevent } \\
\text { injuries, reduce hazards and } \\
\text { increase awareness }\end{array}$ & $\begin{array}{l}\text { Before and after study } \\
\text { (non-targeted injuries used for } \\
\text { comparison data). (A) Injury } \\
\text { surveillance system. (B) } \\
\text { Telephone survey } 375 \text { pre-test, } \\
400 \text { post-test }\end{array}$ & $\begin{array}{l}\text { (A) Emergency } \\
\text { Department } \\
\text { presentations. (B) } \\
\text { Self reported injury } \\
\text { (C) Playground } \\
\text { hazards }\end{array}$ & $\begin{array}{l}\text { (A) Decline in attendance rate from } 6594 \\
\text { to } 4821 / 100000 \text { for targeted injuries. } \\
\text { Small decrease in non-targeted injuries. } \\
\text { (B) Decrease in self-reported injuries from } \\
62.7 \text { to } 48.2 / 1000 \text { (not significant). } \\
\text { Increase in injuries requiring medical } \\
\text { attention from } 24.5 \% \text { to } 31.9 \% \text { (not } \\
\text { significant). (C) Some hazard removal in } \\
\text { playgrounds Partially effective/inconclusive } \\
\text { Reasonable/weak evidence }\end{array}$ \\
\hline $\begin{array}{l}\text { Petridou et al } \\
\text { (1997), }{ }^{19} \\
\text { Greece }\end{array}$ & $\begin{array}{l}0-18 \text { years. Older } \\
\text { adults } 65+\text {. } \\
\text { Community based }\end{array}$ & $\begin{array}{l}\text { Multifaceted intervention } \\
\text { with activities for parents, } \\
\text { teachers, and children. } \\
\text { Home visits, counselling on } \\
\text { home hazards }\end{array}$ & $\begin{array}{l}\text { Controlled trial without } \\
\text { randomisation. I=172 } \\
\text { households on island of Naxos } \\
\mathrm{C}=177 \text { households on island } \\
\text { of Spetses }\end{array}$ & $\begin{array}{l}\text { (A) Self report } \\
\text { injuries. (B) } \\
\text { Observed hazards } \\
\text { Attitudes } \\
\text { Knowledge }\end{array}$ & $\begin{array}{l}\text { (A) No difference in accidents reported in } \\
\text { I and C. (B) For I: improvements on } 11 \\
\text { out of } 28 \text { hazards C: improvements in } 1 \\
\text { out of } 28 \text { hazards Partially effective } \\
\text { Reasonable/weak evidence }\end{array}$ \\
\hline $\begin{array}{l}\text { Lindquist et al } \\
\text { (1999), }{ }^{20} \\
\text { Sweden }\end{array}$ & $\begin{array}{l}\text { General } \\
\text { population. } \\
\text { Community based }\end{array}$ & $\begin{array}{l}\text { Motala WHO Safe } \\
\text { Community All age, all } \\
\text { injury programme. Traffic, } \\
\text { sport, and recreation } \\
\text { targeted }\end{array}$ & $\begin{array}{l}\text { Before and after study } \\
\mathrm{I}=\text { Motala } 41000\end{array}$ & $\begin{array}{l}\text { Hospital } \\
\text { admissions, severity } \\
\text { and length of stay }\end{array}$ & $\begin{array}{l}\text { In under } 20 \text { age group, total injuries } \\
\text { decreased by } 18 \% \text { between before and } \\
\text { after period Inconclusive Reasonable/weak } \\
\text { evidence }\end{array}$ \\
\hline $\begin{array}{l}\text { Ytterstad et al } \\
\text { (1998), } \\
\text { Norway }\end{array}$ & $0-4$ years & $\begin{array}{l}\text { Harstaad WHO Safe } \\
\text { Community Programme } \\
\text { All age, all injury prevention } \\
\text { Educational activities in a } \\
\text { range of settings. Mass } \\
\text { media }\end{array}$ & $\begin{array}{l}\text { Controlled trial without } \\
\text { randomisation. } I_{1}=\text { Harstaad } \\
23000, I_{2}=6 \text { towns around } \\
\text { Harstaad } 14000 \\
C=\text { Trondheim } 134000\end{array}$ & $\begin{array}{l}\text { Morbidity data } \\
\text { Outpatient } \\
\text { admissions records }\end{array}$ & $\begin{array}{l}\text { Decrease in burn injury rates at } 51.5 \% \text { in } \\
\mathrm{I}_{1}, 40.1 \% \text { in } \mathrm{I}_{2} \text { and increase of } 18.1 \% \text { in C } \\
\text { Inconclusive Reasonable/weak evidence }\end{array}$ \\
\hline
\end{tabular}

$\mathrm{C}=$ control; $\mathrm{I}=$ intervention.

However, the studies published are not evenly spread across the various injury types and do not reflect the injury burden. The studies reviewed included a relatively large number $(10 / 42)$ relating to the use of bicycle helmets. The prevention of child pedestrian injuries was addressed in a relatively small number of studies (and exclusively in only one study) despite the fact that it remains the main cause of child injury death. This bias in the literature may reflect the fact that some injury areas can be researched relatively easily compared with others. Injuries where there is a simple, single intervention (such as a bicycle helmet) that can be evaluated relatively simply within closed systems (for example, schools) are more likely to receive research attention. ${ }^{26}$

Recent studies have included a larger concentration of studies focusing on high risk or socially deprived groups. These studies represent an important addition to the literature. In one such study, parent volunteers carried out the child pedestrian training programme. Using locally available resources may be more likely to result in low cost and sustainable child injury prevention programmes. As in our earlier review, the cost of the interventions was rarely considered in the studies included here.

The quality of the evidence was very mixed. Fewer than a third of the studies used research designs where the evidence was rated as good/ reasonable. The remaining studies had weaker designs and it was therefore more difficult to interpret and have confidence in the results. Experimental methods are not always appropriate to evaluate injury prevention programmes, especially where more than one injury type is targeted or where interventions are aimed a large groups. Nevertheless, the inclusion of appropriate control groups, well defined target groups, and an adequate sample size increases the strength of the evidence. Few studies included process information; such information is useful to understand issues such

Table 6 Mass media general interventions

\begin{tabular}{|c|c|c|c|c|c|}
\hline $\begin{array}{l}\text { Author, date, } \\
\text { and country }\end{array}$ & $\begin{array}{l}\text { Injury target } \\
\text { group and setting }\end{array}$ & Aims and content of intervention & Study type and sample size & $\begin{array}{l}\text { Outcome } \\
\text { measures }\end{array}$ & Key results \\
\hline $\begin{array}{l}\text { Gielen et al } \\
\quad(1996),{ }^{22} \\
\text { USA }\end{array}$ & $\begin{array}{l}7 / 8 \text { years. Rural } \\
\text { area. Safety } \\
\text { centre }\end{array}$ & $\begin{array}{l}2 \text { day visit to community safety } \\
\text { centre. Exhibitions, videos, } \\
\text { simulations, skills training }\end{array}$ & $\begin{array}{l}\text { Before and after study. No } \\
\text { control. } \mathrm{I}_{1}=158 \\
\text { Parents }=302\end{array}$ & $\begin{array}{l}\text { Reported } \\
\text { behaviour. } \\
\text { Attitudes. } \\
\text { Knowledge }\end{array}$ & $\begin{array}{l}\mathrm{I}_{1}: \text { knowledge scores increased from } 58 \% \text { to } \\
78 \% ; 1 / 3 \text { of parents reported making safety } \\
\text { changes in home Effective in some groups } \\
\text { Reasonable/weak evidence }\end{array}$ \\
\hline $\begin{array}{l}\text { Sundelin et al } \\
\text { (1996), } \\
\text { Sweden }\end{array}$ & $\begin{array}{l}0-6 \text { years and } \\
\text { their parents. } \\
\text { Mass media }\end{array}$ & $\begin{array}{l}\text { National TV campaign; } 8 \times 10 \\
\text { minute programmes. Local } \\
\text { campaign-families received } \\
\text { personal letters }\end{array}$ & $\begin{array}{l}\text { Controlled trial without } \\
\text { randomisation. } \mathrm{I}=1699 \\
\mathrm{C}=144\end{array}$ & $\begin{array}{l}\text { Reported } \\
\text { behaviour. } \\
\text { Attitudes }\end{array}$ & $\begin{array}{l}59 \% \text { of I and } 43 \% \text { of } \mathrm{C} \text { had seen at least one } \\
\text { programme } 33 \% \text { of those seeing } 2+ \\
\text { programmes reported behaviour changes } \\
\text { Inconclusive Reasonable/weak evidence }\end{array}$ \\
\hline $\begin{array}{l}\text { Marsh and } \\
\quad \text { Kendrick } \\
(1998),{ }^{24} \mathrm{UK}\end{array}$ & $\begin{array}{l}\text { Primary health } \\
\text { care team } \\
\text { members. } \\
\text { Training setting }\end{array}$ & $\begin{array}{l}\text { One day multidisciplinary } \\
\text { workshop to increase knowledge }\end{array}$ & $\begin{array}{l}\text { Controlled trial without } \\
\text { randomisation. } \mathrm{I}=58, \\
\mathrm{C}=58\end{array}$ & $\begin{array}{l}\text { Reported } \\
\text { behaviour. } \\
\text { Attitudes. } \\
\text { Knowledge }\end{array}$ & $\begin{array}{l}\text { Significant but small increases in knowledge } \\
\text { in I. Health visitors-some changes in } \\
\text { reported practice Partially effective } \\
\text { Reasonable/weak evidence }\end{array}$ \\
\hline
\end{tabular}

$\mathrm{C}=$ control; $\mathrm{I}=$ intervention. 
Table 7 What interventions work? (that is, reduce injury or change behaviour). Bold type indicates areas where there is new evidence or increased evidence, italic $=$ injury reduction, and roman = behavioural change

INTERVENTIONS IN THE ROAD ENVIRONMENT

(Good evidence ${ }^{\star \star \star}$, reasonable evidence ${ }^{\star \star}$, some evidence ${ }^{\star}$ )

General

Area wide urban safety measure

$20 \mathrm{mph}$ zones

Pedestrian injuries

Education/enforcement aimed at driver

Education aimed at child/parent

Bicycle injuries

Bicycle training

Bicycle helmet educational campaigns

Bicycle helmet legislation

Car passengers

Child restraint educational campaigns

Seat belt educational campaigns

Child restraint loan schemes

Child restraint legislation

Bus passengers

Education aimed at child

Injury reduction ${ }^{\star \star}$

Injury reduction ${ }^{\star * *}$

Behaviour change ${ }^{\star \star \star}$

Behaviour change*

Behaviour change ${ }^{\star \star}$

Injury reduction *

Behaviour change $\star \star$

Behaviour change ${ }^{\star \star}$

Behaviour change $e^{\star \star \star}$

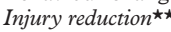

Behaviour change ${ }^{\star \star}$

Behaviour change ${ }^{\star \star}$

Behaviour change $e^{\star \star \star}$

Behaviour change $e^{\star \star \star}$

Injury reduction ${ }^{\star \star}$

Behaviour change ${ }^{\star}$

INTERVENTIONS IN THE HOME ENVIRONMENT

General

Product design

Safety devices

Burns and scalds

Smoke detector promotion programmes

Tap water temperature reduction

Parent and child education

Poisoning

Child resistant packaging

Parent education

Falls prevention

Window bars (education and environmental modification and Behavioural change ${ }^{\star \star}$ legislation)

Parent education

General campaigns

Parent education on hazard reduction

\section{INTERVENTIONS IN THE LEISURE ENVIRONMENT}

\section{Drowning}

Parent and child education

Adult supervision of public swimming pools, beaches, etc

Pool design and protection

Play and leisure injuries

Environment improvement-playground layout,

equipment and surfacing

Training schemes for adult supervision

Protective equipment

Injury reduction ${ }^{\star}$

Injury reduction $\star$

Behaviour change ${ }^{\star \star}$

Behaviour change ${ }^{\star}$

Injury reduction ${ }^{\star}$

Hazard reduction *

Little evidence

Injury reduction ${ }^{\star}$

COMMUNITY BASED STUDIES

Programmes targeting a range of injury types in a range of different groups

Behaviour change $e^{\star \star}$

Injury reduction ${ }^{\star \star}$
Injury reduction ${ }^{\star}$

2 Clamp M, Kendrick D. A randomised controlled trial of general practitioner safety advice for families with children under 5 years. $B M \mathcal{F}$ 1998;316:1576-9.

3 Thompson R, Edwards P, Jarvis S, et al. Childhood accidents: is it time to prescribe safety equipment? Community Practitioner 1998;71:138-40.

4 Kendrick D, Marsh P, Fielding K, et al. Preventing injuries in children: cluster randomised controlled trial in primary care. BMF 1999;318:980-3.

5 Mallonee S, Istre G, Rosenberg M, et al. Surveillance and prevention of residential-fire injuries. $N \mathrm{Engl} F \mathrm{Med}$ 1996;335:27-31.

6 McConnell C, Leeming F, Dwyer W. Evaluation of a fire-safety training program for preschool children. Fournal of Community Psychology 1996;24:213-27.

7 Shults R, Sacks J, Briske L. Evaluation of three smoke detector promotion programs. Am $\mathcal{F}$ Prev Med 1998;15: 165-71.

8 DiGuiseppi C, Slater S, Roberts I, et al. The "Let's Get Alarmed" initiative: a smoke alarm giveaway programme. Inj Prev 1999;5:177-82.

9 King L, Thomas M, Gatenby K, et al. "First Aid for Scalds" campaign: reaching Sydney's Chinese, Vietnamese, and Arabic speaking communities. Inj Prev 1999;5:104-8.

10 Rodgers G. The safety effects of child-resistant packaging for oral prescription drugs: two decades of experience. fAMA 1996;275:1661-5.

11 Liller K, Craig J, Crane N, et al. Evaluation of a poison prevention lesson for kindergarten and third grade students. Inj Prev 1998;4:218-21.

12 D'Argenio P, Cafaro L, Santonastasi F, et al. Capodanno Senza Danno: the effects of an intervention program on fireworks injuries in Naples. Am F Public Health 1996;86: 84-6.

13 Malinowska-Cieslik M, Borne B. Prevention of mushroom poisoning of children: effectiveness of a community-based school education programme. Health Education Research 1998;13:13-23

14 Withaneachi D, Meehan T. Promoting safer play equipment in primary schools: evaluation of an educational campaign. Health Promotion fournal of Australia 1998;8:125-9.

15 Bennett E, Cummings P, Quan L, et al. Evaluation of a drowning prevention campaign in King County, Washington. Inj Prev 1999;5:109-13.

16 Sibert J, Mott A, Rolfe K, et al. Preventing injuries in public playgrounds through partnership between health services
and local authority: community intervention study. BMf and local authority

17 Svanström L, Ekman R, Schelp L, et al. The Lidköping accident prevention programme - a community approach to preventing childhood injuries in Sweden. Inj Prev 1995; 1:169-72.

18 Day L, Ozanne-Smith J, Cassell E, et al. Latrobe Valley better health project. Evaluation of injury prevention program 1992-1996. (Report No 114.) Melbourne: Monash University Accident Research Centre/Victorian Health Promotion Foundation, 1997.

19 Petridou E, Tolma E, Dessypris N, et al. A controlled evaluation of a community injury prevention project in two ation of a community injury prevention project
Greek islands. Int 7 Epidemiol 1997;26:173-9.

20 Lindquist K, Timpka T, Schelp L, et al. The WHO safe community program for injury prevention: evaluation of the impact on injury severity. Public Health 1998;112:38591

21 Ytterstad B, Smith G, Coggon C. Harstad injury prevention study: prevention of burns in young children by community based intervention. Inj Prev 1998;4:176-80.

as programme reach and impact and assists in study replication in different settings.

Given the complexity of the injury problem, there are unlikely to be simple solutions which result in dramatic changes in injury rates. Over the past decade, our knowledge has increased incrementally and the last four years has seen the publication of further evidence on strategies to reduce the injury burden. There remains a need for further research. A concerted attempt is needed, however, to implement established interventions, both nationally and locally.

The results are summarised in table 7 . This project has been funded by England's NHS Executive
National R\&D Programme in Mother and Child Health (CH 10-21).

1 Bablouzian L, Freedman E, Wolski K, et al. Evaluation of a community based childhood injury prevention program. Inj Prev 1997;3:4-16.
22 Gielen A, Dannenberg A, Ashburn N, et al. Teaching safety: evaluation of a children's village in Maryland. Inj Prev 1996;2:26-31.

23 Sundelin C, Rosmussen F, Berfenstram R, et al. Information through television: does it promote child safety? Inj Prev 1996;2:36-40.

24 Marsh P, Kendrick D. Injury prevention training: is it effective? Health Education Research 1998;13:47-56.

25 Towner E, Dowswell T, Jarvis S. Reducing childhood accidents. review. London: Health Education Authority, 1993.

26 Towner E, Dowswell T, Simpson G, et al. Health promotion in childhood and young adolescence for the prevention of unintentional injuries. London: Health Education Authority, 1996.

27 Thomson J, Whelan K. A community approach to road safety education using practical training methods. The Drumchapel project. (Road safety research report No 3.) London: project. (Road safety research

28 Parkin P, Hu X, Spence L, et al. Evaluation of a subsidy program to increase bicycle helmet use by children of gram to increase bicycle helmet use by
low-income families. Pediatrics $1995 ; 96: 283-7$.

29 Britt J, Silver I, Rivara F. Bicycle helmet promotion among low income preschool children. Inj Prev 1998;4:280-3.

30 Hendrickson S, Becker H. Impact of a theory based intervention to increase bicycle helmet use in low income children. Inj Prev 1998;4:126-31.

$31 \mathrm{Ni} \mathrm{H}$, Sacks J, Curtis L, et al. Evaluation of a statewide bicycle helmet law via multiple measures of helmet use. Arch Pediatr Adolesc Med 1997;151:59-65.

32 Hazinski M, Eddy V, Morris J. Children's traffic safety program: influence of early elementary school safety education on family seat belt use. $\mathcal{F}$ Trauma 1995;39:1063-8 The effectiveness of health promotion interventions: a literature 